\title{
BUTTERFLY ASSEMBLAGES IN FRAGMENTED MEADOW HABITATS OF THE PRE-CARPATHIAN LOWLAND (BEREG PLAIN, SW UKRAINE)
}

\author{
SZANYI, SZ. ${ }^{*}-$ NAGY, A. ${ }^{2}-$ VARGA, Z. ${ }^{1}$ \\ ${ }^{1}$ University of Debrecen, Faculty of Science and Technology, Department of Evolutionary \\ Zoology, 4032. Debrecen, Egyetem tér 1 \\ ${ }^{2}$ University of Debrecen, Faculty of Agricultural and Food Sciences and Environment \\ Management, Institute of Plant Protection, 4032 Debrecen, Böszörményi út 138. \\ * Corresponding author \\ e-mail: szanyiszabolcs@gmail.com \\ (Received 21 $1^{\text {st }}$ Dec 2013; accepted $7^{\text {th }}$ Jan 2015)
}

\begin{abstract}
The butterfly assemblages of grassland habitats in the Transcarpathian part of the Bereg plain were studied with standard transect walk methods in 2012 and 2013, in 6 different sites (14 transects), in all sites with 4 and 5 repetitions per year. To sum up, we observed 63 butterfly species in more than 4800 individuals. $25 \%$ of these species is under protection in Hungary. Considering the faunal types, the widely distributed and generalist Euro-Siberian species predominate, but with significant presence of HoloMediterranean and southern Continental elements. The less disturbed habitats surrounded by natural forests have shown the highest species diversity (Shannon-Wiener). The assemblages were compared with multivariate methods (PCA, cluster, Bray-Curtis) . Three main groups of habitats were separated and characterised by indicator species (IndVal). The positive effect of nature-like forest fringe and scrubby structures was demonstrated. According to our results the quality of habitats is more relevant for species diversity than size and/or isolation of habitats.
\end{abstract}

Keywords: compositional diversity, dominants, biogeographical components, indicator species, protected species

\section{Introduction}

Large parts of Europe suffer from loss of biodiversity (e.g. May et al., 1995; Hambler and Speight, 2004; Thomas et al., 2004; Thomas, 2005), despite of the efforts to stop or at least decelerate this process (see: Natura 2000). Especially in densely populated and industrialised West and Central European countries, the current extinction of many species is strongly connected to habitat fragmentation and loss (Andrén, 1996; Fahrig, 1997) resulting from the destruction of natural and semi-natural habitats (Wilcox and Murphy, 1985; Saunders et al., 1991; Harrison and Bruna, 1999). In other parts of Europe, the abandoning of traditional land use, connected with social changes represents the major threat for biodiversity (Warren, 1997; Wenzel et al., 2006; Schmitt and Rákosy, 2007).

Butterflies are considered as sensitive indicators of habitat changes since they are known to respond quickly to a number of environmental parameters, e.g. vegetation structure and composition (Erhardt and Thomas, 1991; Rákosy and Schmitt, 2011). They are also well suitable for monitoring of changes since they are well understood taxonomically, and easily recognized and marked in the field. Lepidoptera can also be used as umbrella species (sustaining habitat to conserve this species will also conserve many other taxa) for biodiversity conservation (New, 1997). 
The sites of our surveys are lying on the immediate continuation of the Pannonian lowland (Szatmár-Bereg plain) which is a traditional, low input agricultural region with several rests of the natural and semi-natural vegetation: lowland oak-hornbeam forests, hard- and softwood gallery forests, humid meadows and forest clearings (Simon, 1952), but recently also with abandoned pastures and fallow lands. A considerable part of the area is dissected by dreanage channels of the former huge peatland which existed here until the last decades of the XIX century. The climate of the Szatmár-Bereg lowland (Kormány, 1976, 2006) is slightly cooler (yearly average $8,9^{\circ} \mathrm{C}$ ) and more continental than the average of the Great Hungarian Plain (January $-3,4^{\circ} \mathrm{C}$ ). The yearly sum of precipitation is also higher, about $\mathrm{mm}$ in average $(609-640 \mathrm{~mm})$. Biogeographically it belongs to the Pannonian region, however, with significant Carpathian influences in some groups of terrestrial invertebrates (land gastropods, ground beetles, see: Deli et al., 1997; Magura et al. 1997; Ködöböcz and Magura, 1999; Gálik et al, 2001). Our surveys were carried out near to the village Nagydobrony, partly in the "Nagydobrony Game Reserve" or in adjacent territories.

The aims of our surveys were:

- To record the species composition and species' relative frequencies of the butterfly assemblages.

- To compare the two years of survey considering whether has changed (i) the number of species, (ii) relative frequency of species, (iii) the Shannon-Wiener diversity index.

- To register the similarities and differences betwwen the composition of butterfly assemblages of different habitats.

- To search for indicator species of habitat types and for correlations between vegetation and butterfly assemblages.

- To evaluate the results for the nature conservation management of surveyed sites.

\section{Material and Methods}

The surveys were carried ot by standard transect walks in 2012 and 2013 in four and five repetitions, respectively (2012: 16-18. 06; 11-14. 07; 04-06. 08; 06-08. 09; 2013: 05-06. 06; 05-08. 06; 05-08. 07; 21-22. 07.). We designated on 6 sites 14 transects (length $50 \mathrm{~m}$ ) and recorded all butterflies $2.5 \mathrm{~m}$ to their right, $2.5 \mathrm{~m}$ to their left, $5 \mathrm{~m}$ ahead of them and $5 \mathrm{~m}$ above them. Visits were conducted when the temperature was above $20^{\circ} \mathrm{C}$ in sunny weather, without strong wind and rain (see: Van Swaay et al., 2002). Most butterflies were readily identified by observation. The dubious specimens were captured by net and they were either immediately released after identification or preserved as voucher specimen for exact determination (e.g. some Lycaenidae or Melitaea species).

During each transect walks some standard values of vegetation were measured (species composition, relative cover in $\%$, height of vegetation, etc.). From these data here we only use the relative cover of flowering forbs (dicotyledones) as a proxy of vegetation quality from respect the butterflies (Table 1).

The composition of butterfly assemblages was compared by Principal Component (PCoA) and cluster analysis in which the Bray-Curtis distance was used, in clustering the MISSQ (incremental sum of squares method of Ward and Orlóci) was chosen(Podani, 1997a). The assemblages were compared in each year separately and 
also with combined data of both years. The analyses were carried out with the programme package SynTax (Podani, 1997).

Table 1. Cover of flowering herbaceous dicotyledones (\%)

\begin{tabular}{|c|c|c|c|c|c|c|}
\hline Data 2012 & Szapat & Körerdö & Felsö-erdö & Reserve I. & Reserve II. & Kismakkos \\
\hline 16-19. 06. & 21 & 24 & 53 & 37 & 48 & 41 \\
\hline $11-14.07$. & 25 & 36 & 61 & 43 & 57 & 47 \\
\hline $02-06.08$. & 24 & 38 & 66 & 44 & 63 & 53 \\
\hline 08-10. 09. & 22 & 28 & 45 & 39 & 41 & 44 \\
\hline Min-Max & $21-25$ & $24-38$ & $45-66$ & $37-44$ & $41-63$ & $41-53$ \\
\hline
\end{tabular}

\begin{tabular}{|c|c|c|c|c|c|c|}
\hline Data 2013 & Szapat & Körerdö & Felsö-erdö & Reserve I. & Reserve II. & Kismakkos \\
\hline 05-06. 06. & 29 & 27 & 55 & 41 & 47 & 45 \\
\hline $06-08.07$. & 36 & 34 & 62 & 48 & 54 & 52 \\
\hline 21-23. 07. & 38 & 41 & 68 & 52 & 57 & 54 \\
\hline 13-15. 08. & 33 & 38 & 61 & 49 & 51 & 51 \\
\hline 30. 08-01.09 & 27 & 24 & 47 & 33 & 37 & 39 \\
\hline Min-Max & $27-38$ & $24-41$ & $47-68$ & $33-52$ & $37-57$ & $39-54$ \\
\hline
\end{tabular}

The quantitative character species, i.e. indicator species of the assemblages were classified by the IndVal method, using the programme package IndVal (Dufrêne and Legendre, 1997). We hierarchically classified the species according to their fidelity (constancy within group). The IV value of species is the highest (100) if the given species is present in all samples of the given group and is also exclusive for this group of samples. The program calculates the IV values of each species for each hierarchic level of clustering and the maximum value will be considered as indicator value of the given species. The significance of IV values was determined by randomisation (1000 iterations).

\section{Results}

\section{Faunistic records}

During our surveys we registered 63 butterfly species in more than 4800 individuals. From these, six species occurred in all habitats in both years: Pyrgus malvae, Thymelicus silvestris, Pieris rapae, Polyommatus icarus, Coenonympha pamphilus, Maniola jurtina. These are known as generalist species, three of them are connected to grasses (Poaceae) and three to herbaceous forbs. Three further species were observed in all habitats with the exception of the extremely dry ones: L. sinapis/juvernica, Cupido alcetas, C. argiades. They are connected to Fabeceae species (Lotus, Lathyrus, etc.). The migrant $C$. argiades was observed in both years constantly in relatively high individual numbers.

The species number was consequently the highest in the nearly undisturbed semihumid meadow surrounded by natural hardwood forest with natur-like forest fringe (transitional in Table 2) and the lowest in artificially drained, disturbed abandoned pasture (disturbed in Table 2). It seems to be a general tendency that the nature-like forest fringes support a higher diversity of species, faunal elements and ecological types. These values seem to be independent from the extension of the sampling sites (Table 2). Of course, the number of observed individuals was the smallest on the site with the smallest extension. Furthermore, the species number and the number of 
observed individuals (with one single exception) were slightly higher in 2013 than in 2012, possibly due to higher number of repetitions (5 vs. 4).

Table 2. Basic data of the sampling sites and observed species and individuals

\begin{tabular}{lcccc}
\hline & disturbed, & transitional & humid & sum \\
\hline Mean area & 5.2 & 3.5 & 1.9 & 3.8 \\
Number of sites (samples) & $2(4)$ & $3(6)$ & $1(2)$ & $6(12)$ \\
Species richnes (Stotal) & 33 & 59 & 34 & 63 \\
Mean species/site $(\alpha)( \pm \mathrm{SD})$ & $20.8(3.3)$ & $34.0(3.6)$ & $32.0(1.4)$ & $29.3(7.0)$ \\
Whittaker's S/ $\alpha$ & 1.6 & 1.7 & 1.1 & 2.2 \\
S/ $\alpha$ max & 1.3 & 1.6 & 1.0 & 1.7 \\
Number of specimens & 1018 & 3371 & 420 & 4809 \\
Specimen/site $( \pm \mathrm{SD})$ & $254.5(72.6)$ & $561.8(182.7)$ & $210.0(38.2)$ & $400.8(212.8)$ \\
\hline
\end{tabular}

The whole species composition of assemblages is added as Electronic Appendix to the publication. More than $25 \%$ of the observed species are protected in Hungary, it means that at least some of our sampling sites have a nature conservation importance.

\section{Biogeographical composition of butterfly assemblages}

The sites of our surveys are enbedded into an agricultural landscape and are mostly surrounded by anthropogenic habitats. Thus, the bulk of the fauna is formed by widely distributed Euro-Siberian species with broad ecological tolerance. They do not have any food plant specialisation and occur, as a rule, also in disturbed or anthropogenically transformed habitats. Special biogeographic elements, as Holo-Mediterranean (-West Asiatic), Ponto-Mediterranean, Southern Continental or Boreo-Continental species are much less represented (Fig. 1). The number of migrant (,extra-Palaearctic") species is relatively high.

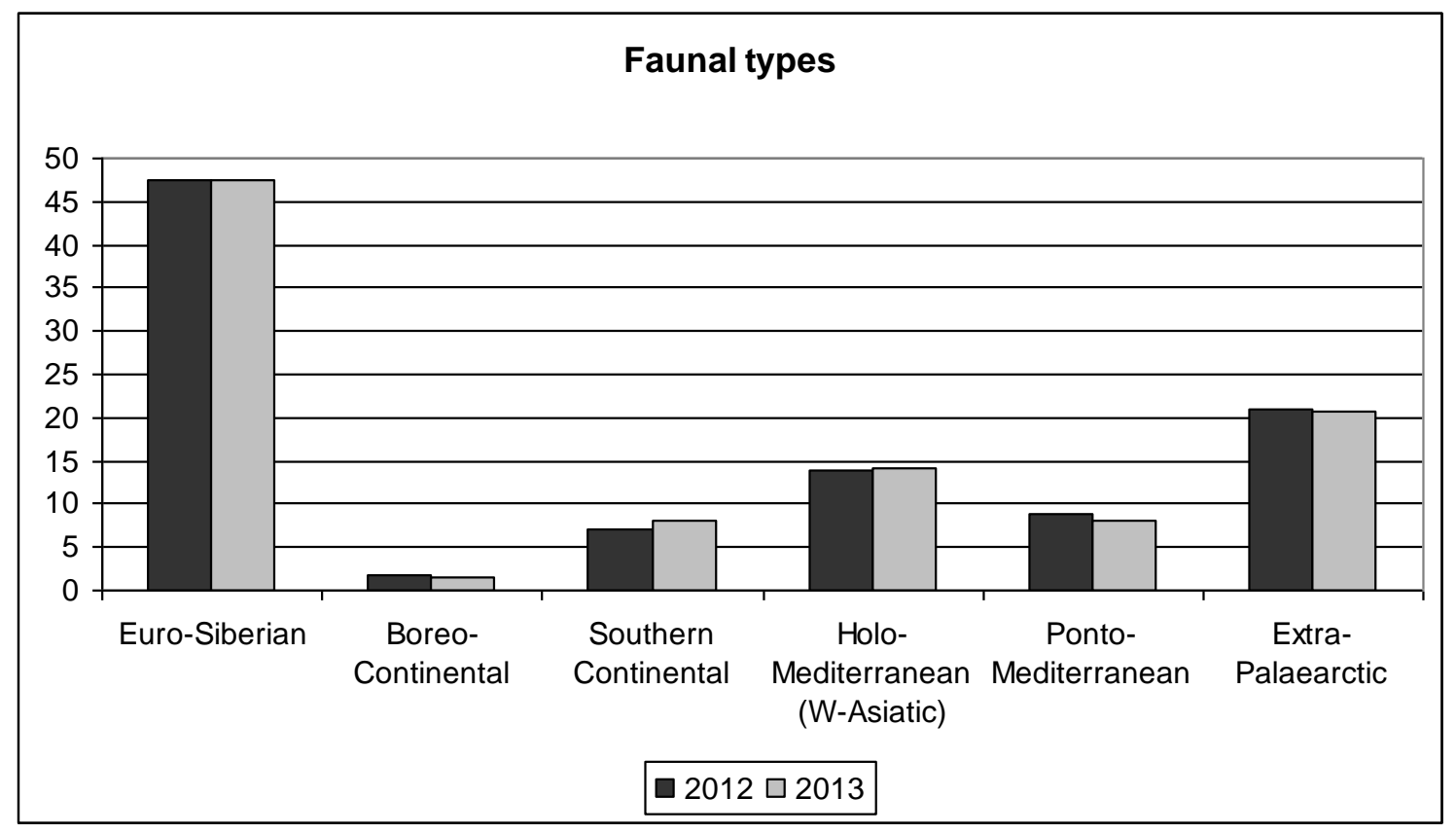

Figure 1. The relative frequency of species numbers belonging to different faunal types. 
The classification of the faunal components was based on the concept of Varga (1977), recognising that the bionomy of the lepidopterans is primarily influenced by the life history of the caterpillars, the larval hostplants, etc. and therefore it can be characterized by a certain type of habitat (like humid vs. dry sward, humid tall forb formations, softwood vs. hardwood forest, etc.). The composition of faunal components (Fig. 2) also proved to be essentially similar to the faunal types since the highly tolerant, euryoecious species predominate. The specialists are mostly connected either to humid habitats, e.g. Lycaena dispar rutila, Boloria selene or scrubby forest skirt formations, as Satyrium species, Neptis sappho, Brenthis daphne, etc. In these respects we could not find any differences between the two consecutive years.

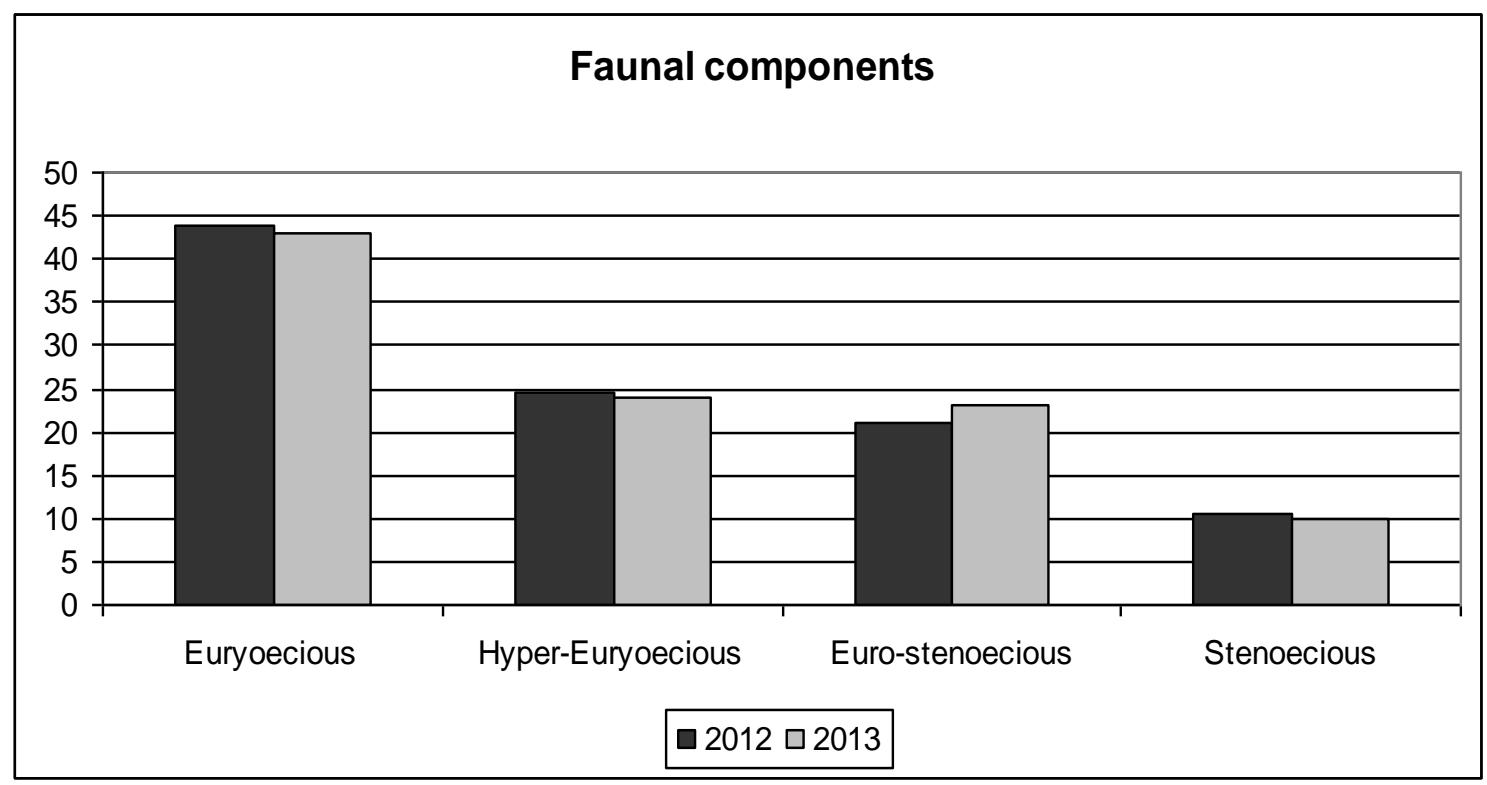

Figure 2. The relative frequency of generalist $v$ s specialist species

\section{Compositional diversity and similarity of butterfly assemblages}

The values of Shannon-Wiener diversity show an increasing gradient from the heavily disturbed (drained and formerly overgrazed) pasture (,Szapat”) to the mosaiclike habitats with scrubby patches and/or nature-like forest fringes (Reserve/Rezervátum I and „Kis-Makkos”). The species diversity of the sites surrounded by forests or naturelike forest fringe structures is nearly at the same level (Fig. 3, see sites 3-6). No significant difference was observed between 2012 and 2013.

The compositional similarity of the assemblages was compared by Principal Component Analysis (PCoA) and they were clustered based on Bray-Curtis distances (programme package SynTax 2000). The ordination was carried out separately for each year but also using the pooled (2012-2013) data of sampling localities.

Three groups of sites were clearly differentiated (Figs 4-5). The drained and disturbed habitats with lower diversity are clearly separated, but also the mostly closed, scrubby habitat, surrounded by forest, seems to be distant from the other ones. The configuration of the sites is essentially the same in both years, the importance of the axes was changed, however. The ordination based on both years also confirms the separation of the three main groups. 


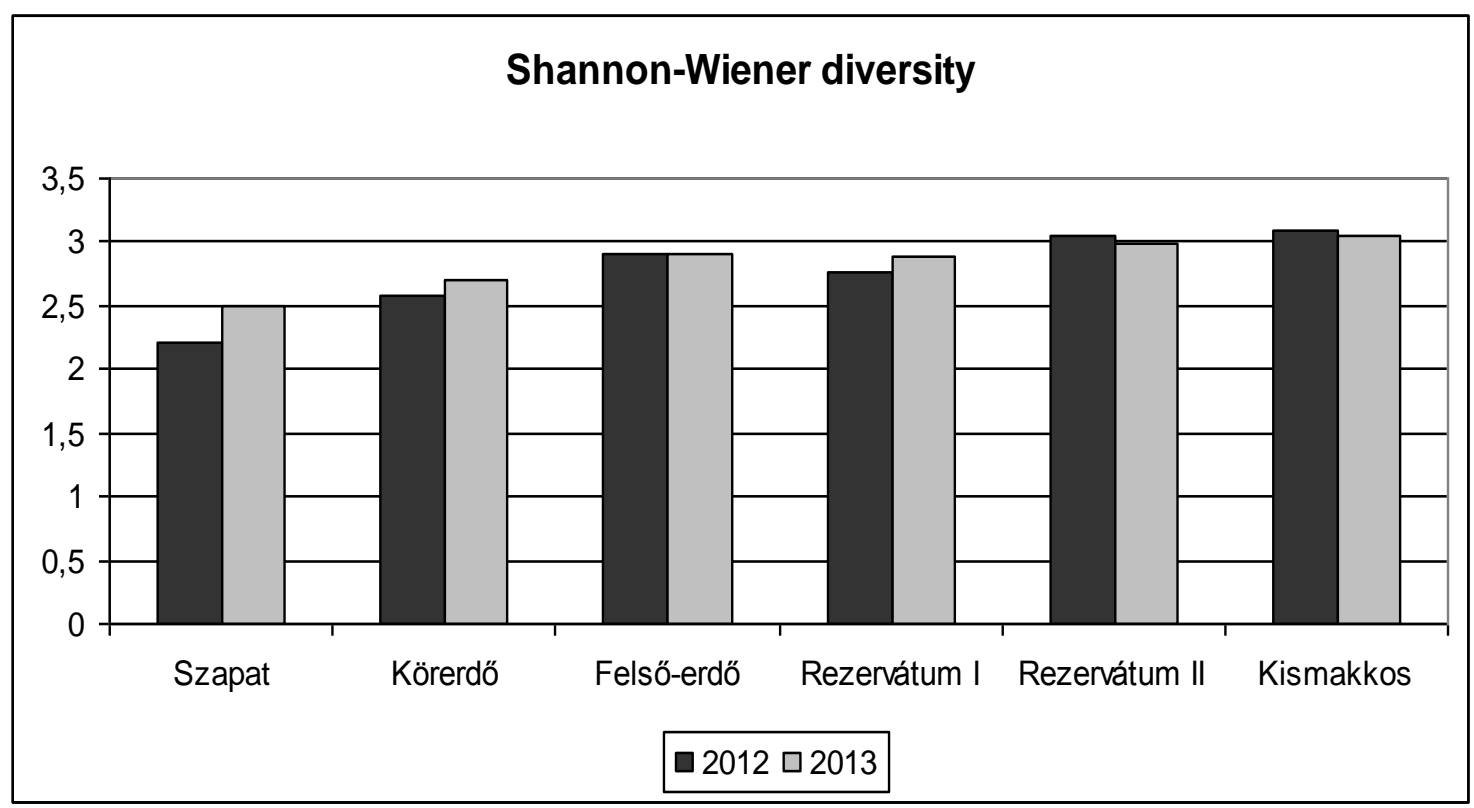

Figure 3. The Shannon-Wiener diversity of butterfly assemblages
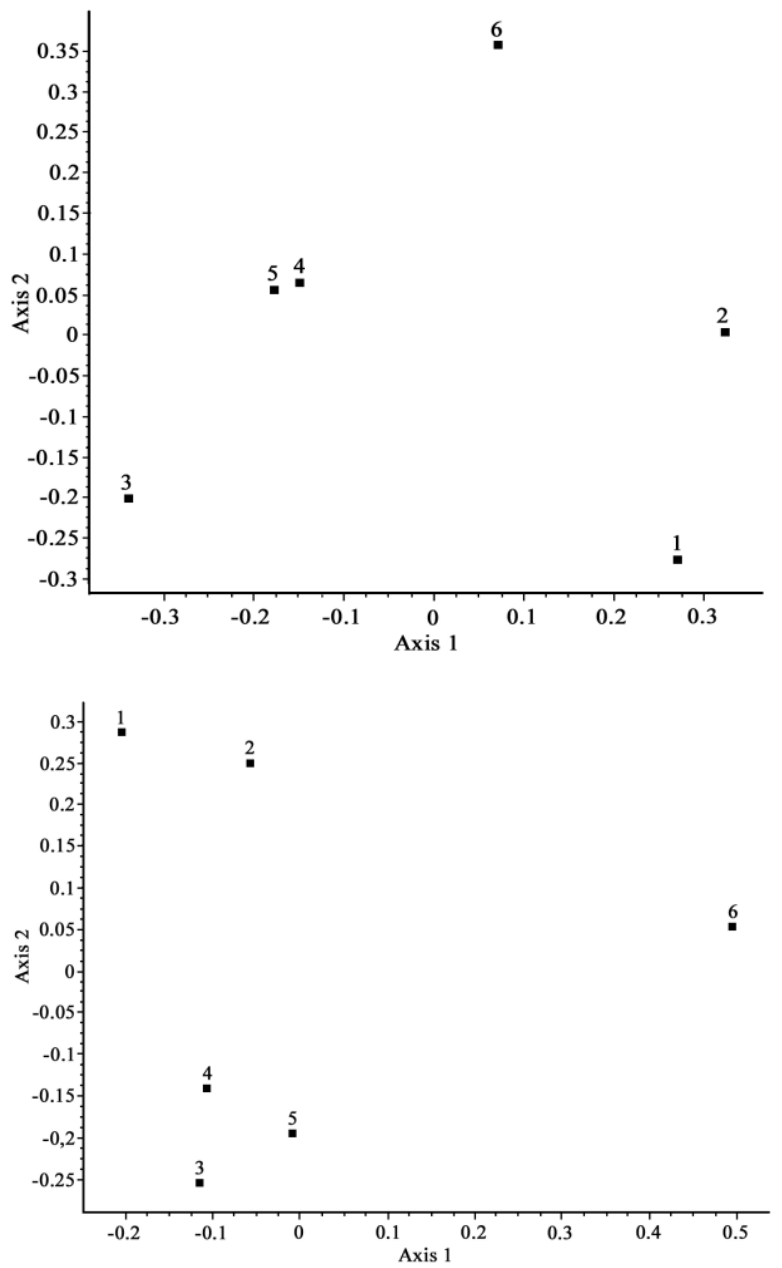

Figure 4. Ordination of the sampled assemblages in 2012 and 2013 (Bray-Curtis) 


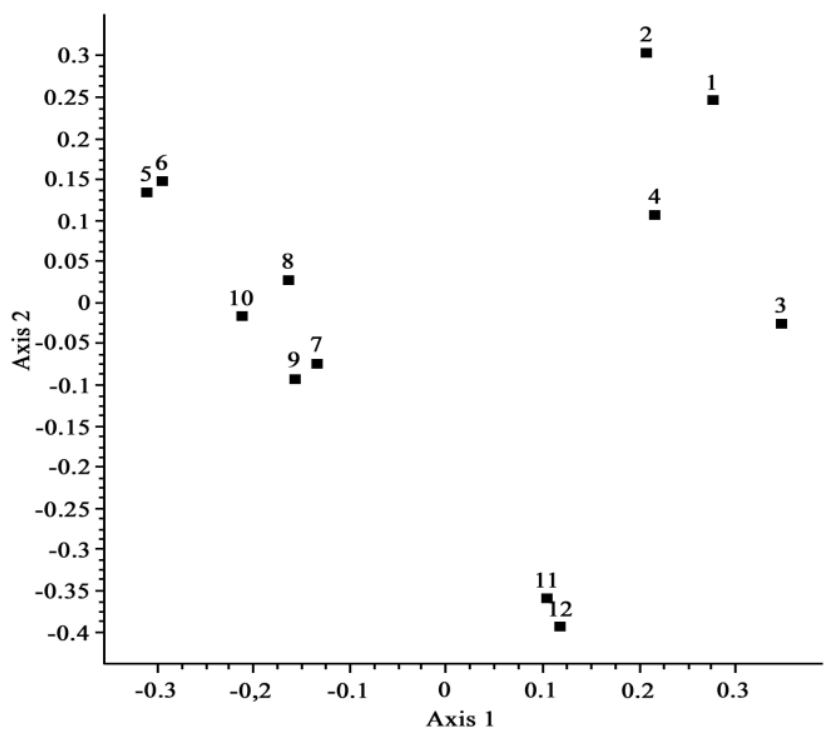

Figure 5. Ordination of the sampled assemblages in both years (Bray-Curtis)

The clustering of sampling sites clearly shows the same pattern (Fig. 6). The basic split is between the disturbed, drained vs. more nature-like or semi-natural habitats. The data of the sampling sites from the both years are usually clustered together.
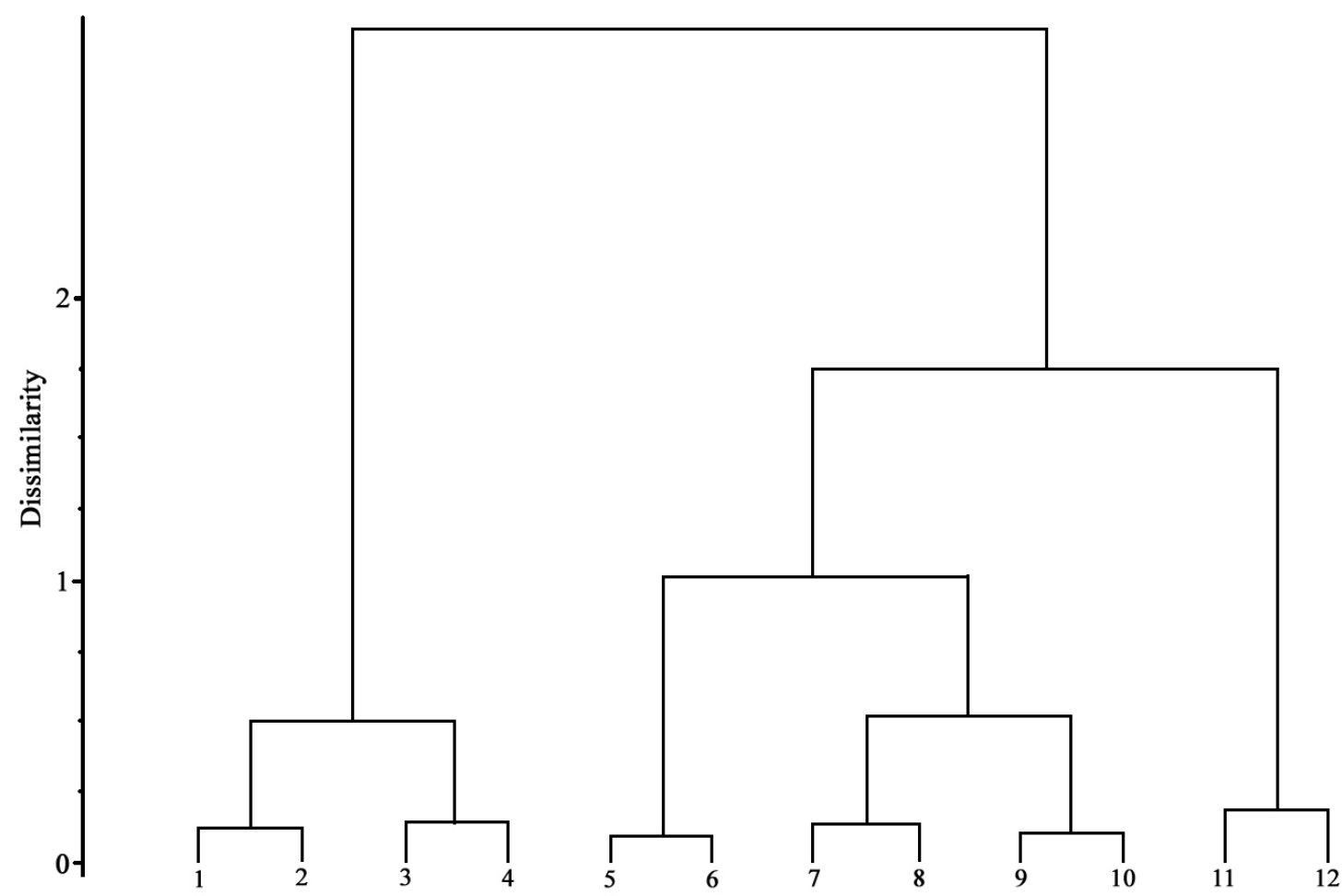

Figure 6. Clustering of sampling sites (Bray-Curtis) 
The dominance-identity of sites shows a completely similar pattern as the BrayCurtis dendrogram. The most disturbed sites (Szapat, Körerdö) show the highest similarity to each other and they are also very dissimilar to all other sites. The second group is formed by sites (5-10) where the meadow is surrounded by nature-like hardwood forests. The third habitat type is mosaic-like, with semi-dry grassy and scrubby patches and nature-like forest fringe structures. This habitat shows a striking differentiation mostly in 2013 from the other ones.

The ordination of the sites was completed with an Indicator Species Analysis (IndVal) (Fig. 7). Seven generalist species are typical for all sampling sites, while 5 vs 5 species characterise the disturbed pasture-like and the more meadow/hayfield-like sites, respectively. We could only differentiate a third hierarchic level of splitting: between mesic-humid habitats surrounded by hardwood stands (6 species) and the patchyscrubby semi-dry habitats (4 species). The conservation biologically significant species are to be found in the species groups typical for mesic and/or scrubby, semi-dry sites. We could not differentiate further sub-groups since the indicator species of the lowest hierarchic level would be very weakly supported.

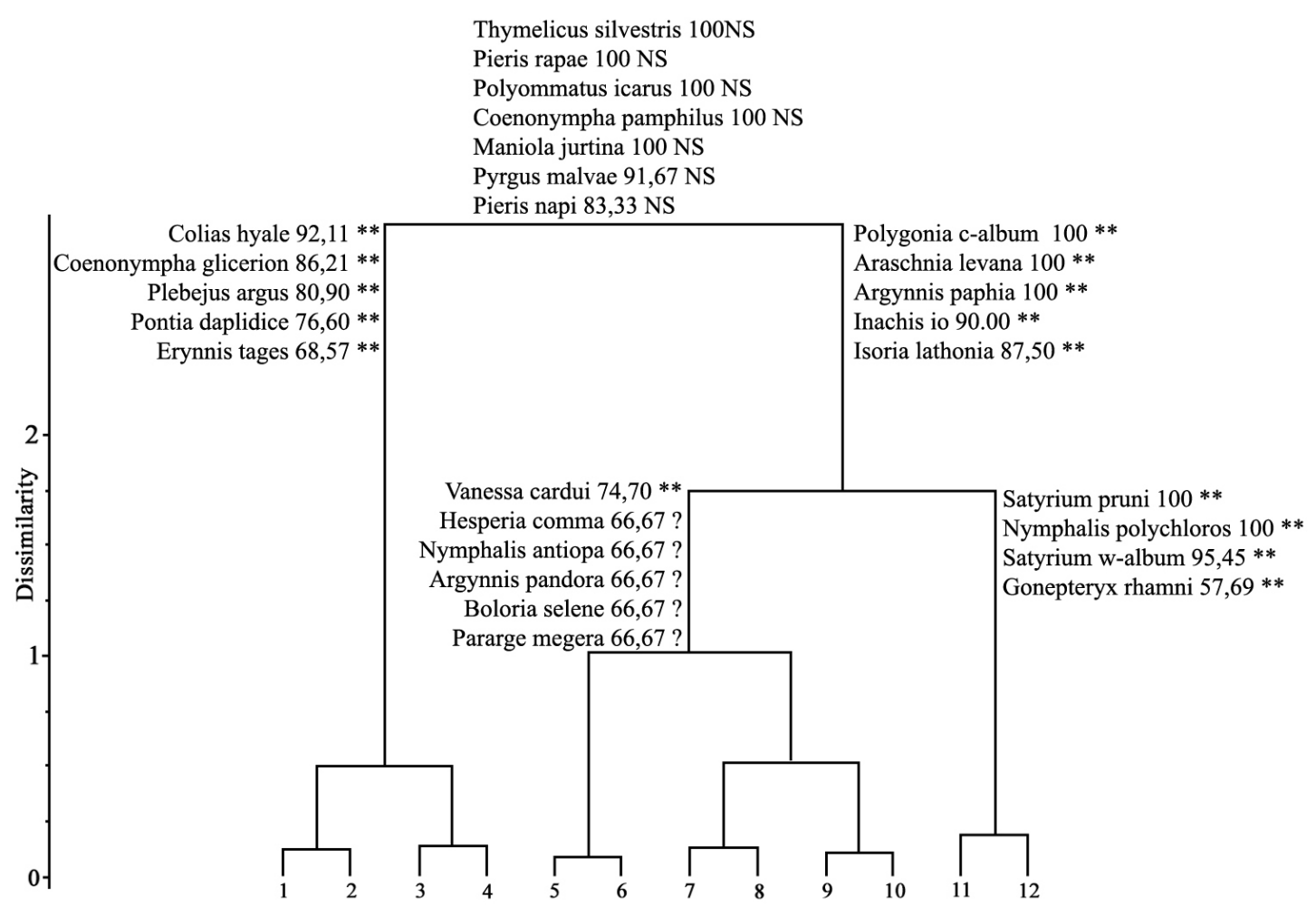

Figure 7. Indicator species of the clustered sites

\section{Discussion}

Habitat fragmentation and loss are known to reduce species richness and to change the community structure (Wilcox and Murphy, 1985; Steffan-Dewenter and Tscharntke, 1999, 2000; Tscharntke et al., 2002a, b). These negative processes are mostly connected with the alteration in land use practices causing habitat loss and fragmentation and hence they are also the main factors modifying species communities (Foster and Boose, 
1992; Austrheim et al., 1999; Cousins and Eriksson, 2001; Maes and Van Dyck, 2001). These changes are particularly dramatic for butterfly species (Bourn and Thomas, 2002; Van Swaay, 2002; Wenzel et al., 2006). The decline of many butterfly species across Europe (León-Cortés et al., 2000; Maes and Van Dyck, 2001; Van Swaay et al., 2011) highlights the need to identify the factors influencing species diversity and characteristic habitats for contemporary conservation action.

The agriculturally dominated mosaic landscapes are mostly suitable to identify the situations in which species diversity is high and can be sustained and in which the species diversity is in decline. Riverine lowlands like the Bereg plain, may represent especially valuable fields for such surveys. In such landscapes the traditional land use often preserved more or less natur-like gallery forests and floodplain habitats but the regulation of waterways, the drainage of plains with fluctuating humidity and also the abandoning the traditional land use practices strongly transformed or destroyed large areas. Thus we have contrasting habitats in different extension. Therefore we have to put and discuss numarous questions.

It is one of the most frequently declared working hypotheses that the strong disturbance leads to dominance of generalist species and causes the decline of the more specialist ones, and these processes are usually connected with some homogenisation in the composition of species assemblages. Here we can observe a situation in which the two components can be separated, The dominance of generalist species seems to be evident in both respect: in geographical range and in the lack of connection to special habitats. We cannot observe however, any homogenisation of assemblages, as we can see it from the ordinations. But, the other side of the coin is the unexpected high frequency of migrant species of extra-Palearctic origin. Of course, we need further, at least mid-term surveys to clarify: is there a trend connected with the climate change or we only have seen occasional events.

The other frequent question is whether the size vs quality of habitat patches is more relevant for sustaining species diversity. Here we have seen essentially three different habitat types in very different extensions. Our results clearly demonstrate that the extended but heavily disturbed, drained site(s) cannot support any species rich assemblages. Oppositely, the site with smaller extension but with nature-like forestfringe structures can sustain a nearly so rich assebly than the much larger meadows of the „Reserve". To measure the „quality” we used the simplest proxy, the relative cover of flowering herbaceous forbs in the times of the transect walks (Table 1). We can see that these data are essentially similar in all habitats with the exception of the first to sites (Szapat and Körerdö) which were also ahown as habitats of species-poor assemblages. Although we only have some ,anecdotic” information on the earlier land use practices, we can believe that these more disturbed sites with low level of diversity were grazed (or even overgrazed and trampled) while the other meadows were suitable for mowing and were used as hayfields. The more detailed study of soil and vegetation will be necessary in the next step of surveys.

In this connection we also have seen that the forests, and especially the fringe structures can positively influence the species diversity, since numerous butterflies feeding on nectar sources of meadows are connected by their larval foodplants to forest fringes or light-penetrated parts of forests (e.g. Theclini: Satyrium spp., Argynnis paphia, Brenthis daphne). Some other species possibly prefer meadow patches surrounded by forests from micro-climatic reasons, e.g. sheltering from wind, humidity, less extreme fluctuation of temperature, etc. Unfortunately, these questions cannot be 
answered yet. References show that in contrast to broad-scale climatic impacts on biodiversity (e.g. Parmesan, 2006), small-scale impacts influencing the composition of insect assemblages are much less understood. The survey of the small-scale effects of micro-climate, vegetation structure, etc. would essentially improve the understanding of composition in natural communities, especially which harbour specialist species. Moreover, it would enhance the effectivity of conservation measures maintaining species diversity under climate change.

Acknowledgements. This research was supported by the European Union and the State of Hungary, cofinanced by the European Social Fund in the framework of TÁMOP-4.2.4.A/ 2-11/1-2012-0001 'National Excellence Program'.

\section{REFERENCES}

[1] Andrén, H. (1996): Population responses to habitat fragmentation: statistical power and the random sample hypothesis. - Oikos 76:235-242.

[2] Austrheim, G., Gunilla, E., Olsson, A., Grontvedt, E. (1999): Land-use impact on plant communities in seminatural sub-alpine grasslands of Budalen, central Norway. Biological Conservation 87: 369-379.

[3] Bourn, N. A. D., Thomas, J. A. (2002): The challenge of conserving grassland insects at the margins of their range in Europe. - Biological Conservation 104: 285-292

[4] Cousins, S. A. O., Eriksson, O. (2001): Plant species occurrences in a rural hemiboreal landscape: effects of remnant habitats, site history, topography and soil. - Ecography 24:461-469.

[5] Deli, T., Sümegi, P., Kiss, J. (1997): Biogeographical characterisation of the Mollusc fauna on Szatmár-Bereg Plain. - In: Tóth, E. and Horváth, R. (eds): Proceedings of the „Research Conservation, Management” Conference (Aggtelek) 1-5 May 1966. - ANP Füzetek Aggtelek Vol I. pp. 123-129.

[6] Dennis, R. L. H. (1993): Butterflies and climate change. - Manchester University Press, Manchaster

[7] Dufrêne, M., Legendre, P. (1997): Species assemblages and indicator species: the need for flexible asymmetrical approach. - Ecological Monographs 67(3): 345-366.

[8] Erhardt, A., Thomas, J. A. (1991): Lepidoptera as indicators of change in the semi-natural grasslands of lowland and upland Europe. - In: Collins NM (eds) The conservation of insects and their habitats. Academic Press, London

[9] Fahrig, L. (1997): Relative effects of habitat loss and fragmentation on population extinction. - Journal of Wildlife Management 61: 603-610.

[10] Foster, D. R., Boose, E. R. (1992): Patterns of forest damage resulting from catastrophic wind in Central New England, USA. - Journal of Ecology 80:79-98

[11] Hambler, C., Speight, M. R. (2004): Extinction rates and butterflies. - Science 305: 1563.

[12] Harrison, S., Bruna, E. (1999): Habitat fragmentation and large-scale conservation: what do we know for sure? - Ecography 22: 225-232

[13] Ködöböcz, V., Magura, T. (1999): Biogeographical connections of the carabid fauna (Coleoptera) of the Beregi-síkság to the Carpathians. - Folia entomologica hungarica 60: 195-203.

[14] Kormány, Gy. (1976): Szabolcs-Szatmár megye éghajlata. - Szabolcs-Szatmári Szemle 1: 32-40.

[15] Kormány, Gy. (2006): A Szatmár-Beregi síkság klimatikus és domborzati viszonyai, Az OTKA T/F 046821 sz. kutatási program keretében készült tanulmány.

[16] Lawton, J. H., May, R. M. (1995): Extinction rates. - Oxford University Press, Oxford 
[17] León-Cortés, J. L., Cowley, M. J. R., Thomas, C. D. (2000): The distribution and decline of a widespread butterfly Lycaena phlaeas in a pastoral landscape. - Ecological Entomology 25: 285-294

[18] Maes, D., Van Dyck, H. (2001): Butterfly diversity loss in Flanders (north Belgium): Europe's worst case scenario? - Biological Conservation 99: 263-276

[19] Magura, T., Ködöböcz, V., Tóthmérész, B., Molnár, T., Elek, Z., Szilágyi, G., Hegyessy, G. (1997): Carabid fauna of the Beregi-síkság and its biogeographical relations (Coleoptera Carabidae). - Folia Entomologica Hungarica 58: 73-82.

[20] May, R. M., Lawton, J. H., Stork, N. E. (1995): Assessing extinction rates. In Extinction rates (ed. J. H. Lawton and R. M. May), pp. 1-24. Oxford: Oxford University Press.

[21] McGeoch, M. A., Chown, S. L. (1998): Scaling up the value of bioindicators. - Trends in Ecology and Evolution 13(2): 46-47.

[22] New, T. R. (1997): Are Lepidoptera an effective 'umbrella group' for biodiversity conservation? - Journal of Insect Conservation 1: 5-12.

[23] Parmesan, C. (2006): Ecological and evolutionary responses to recent climate change. Annual Review of Ecology and Systematics 37: 637-669

[24] Podani, J. (1997a): Bevezetés a többváltozós biológiai adatfeltárás rejtelmeibe. - Scientia, Budapest $412 \mathrm{p}$.

[25] Podani, J. (1997b): SYNTAX 5.1.: A new version of PC and Macinthos computers. Coenoses 12: 149-152.

[26] Pollard, E., Yates, T. J. (1993): Monitoring butterflies for ecology and conservation. - In: The British Butterfly Monitoring Scheme. Chapman and Hall, London.

[27] Rákosy, L., Schmitt, T. (2011): Are butterflies and moths suitable ecological indicator systems for restoration measures of semi-natural calcareous grassland habitats? Ecological Indicators 11:1040-1045

[28] Roy, D. B., Rothery, P., Moss, D., Pollard, E., Thomas, J. A. (2001): Butterfly numbers and weather: predicting historical trends in abundance and the future effects of climate change. - Journal of Animal Ecology 70: 201-217.

[29] Saunders, D. A., Hobbs, R. J., Margules, C. R. (1991): Biological consequences of ecosystem fragmentation - a review. - Conservation Biology 5: 18-32

[30] Schmitt, T. (2003): Influence of forest and grassland management on the diversity and conservation of butterflies and burnet moths (Lepidoptera: Papilionoidea, Hesperiidae, Zygaenidae). - Animal Biodiversity and Conservation 26 (2): 51-67.

[31] Schmitt, T., Rákosy, L. (2007): Changes of traditional agrarian landscapes and their conservation implications: a case study of butterflies in Romania. - Diversity and Distributions 13: 855-862.

[32] Simon, T. (1952): Montán elemek az Észak-Alfóld fiórájában és növénytakarójában. Annales Biologicae Universitatis Debreceniensis 1:146-174.

[33] Steffan-Dewenter, I., Tscharntke, T. (1999): Effects of habitat isolation on pollinator communities and seed set. - Oecologia 121:432-440

[34] Steffan-Dewenter, I., Tscharntke, T. (2000): Butterfly community structure in fragmented habitats. - Ecology Letters 3:449-456.

[35] Steffan-Dewenter, I., Tscharntke, T. (2002): Insect communities and biotic interactions on fragmented calcareous grasslands - a mini review. - Biological Conservation 104:275-284.

[36] Thomas, J. A., Clarke, R. T. (2004): Extinction rates and butterflies. - Science 305:15631564.

[37] Thomas, J. A., Morris, M. G. (1994): Patterns, mechanisms and rates of extinction among invertebrates in the United Kingdom. - Philosophical Transactions of the Royal Society B 344:47-54.

[38] Thomas, J. A., Morris, M. G. (1995): Rates and patterns of extinction among British invertebrates. - In: Extinction rates (ed. J. H. Lawton and R. M. May), pp. 111-130. Oxford: Oxford University Press. 
[39] Thomas, J. A. (2005): Monitoring change in the abundance and distribution of insects using butterflies and other indicator groups. - Philosophical Transactions of the Royal Society B 360:339-357.

[40] Thomas, J. A., Bourn, N. A. D., Clarke, R. T., Stewart, K. E., Simcox, D. J., Pearman, G. S., Curtis, R., Goodger, B. (2001): The quality and isolation of habitat patches both determine where butterflies persist in fragmented landscapes. - Proceedings of the Royal Society B 268:1791-1796.

[41] Thomas, J. A., Telfer, M. G., Roy, D. B., Preston, C. D., Greenwood, J. J. D., Asher, J., Fox, R., Clarke, R. T., Lawton, J. H. (2004): Comparative losses of British butterflies, birds and plants and the global extinction crisis. - Science 303:1879-1881.

[42] Tscharntke, T., Steffan-Dewenter, I., Kruess, A., Thies, C. (2002a): Characteristics of insect populations on habitat fragments: a mini review. - Ecological Research 7:229-239

[43] Tscharntke, T., Steffan-Dewenter, I., Kruess, A., Thies, C. (2002b): Contribution of small habitat fragments to conservation of insect communities of grassland-cropland landscapes. - Ecological Applications 12: 354-363

[44] Van Swaay, C. A. M. (2002): The importance of calcareous grasslands for butterflies in Europe. - Biological Conservation 104:315-318

[45] Van Swaay, C. A. M., Nowicki, P., Settele, J., Van Strien, A. J. (2008): Butterfly monitoring in Europe: methods, applications and perspectives. - Biodiversity and Conservation 17: 3455-3469

[46] Van Swaay, C., Maes, D., Collins, S., Munguira, M. L., Šašić, M., Settele, J., Verovnik, R., Warren, M., Wiemers, M., Wynhoff, I., Cuttelod, A. (2011): Applying IUCN criteria to invertebrates: how red is the Red List of European butterflies? - Biological Conservation 144(1):470-478

[47] Varga, Z. (1977): Das Prinzip der areal-analytischen Methode in der Zoogeographie und die Faunenelemente-Einteilung der europäischen Tagschmetterlinge (Lep.: Diurna) Acta biologica debrecina 14: 223-285

[48] Warren, M.S.(1997): Conserving Lepidoptera in a changing environment: a perspective from Western Europe - Journal of Insect Conservation 1:i-iv

[49] Wenzel, M., Schmitt, T., Weitzel, M., Seitz, A. (2006): The severe decline of butterflies on western calcareous grasslands during the last 30 years: a conservation problem. Biological Conservation 28:542-552

[50] Whittaker, R. H. (1960): Vegetation of the Siskiyou Mountains, Oregon California Ecological Monographs 30(3):279-338.

[51] Wilcox, B. A., Murphy, D. D. (1985): Conservation strategy: the effects of fragmentation on extinction. - American Naturalist 125:879-887

\section{APPENDIX}

Electronic Appendix: Transect 2012-2013 